\title{
The role of pedology and mineralogy in providing evidence for 5 crime investigations involving a wide range of earth materials
}

\author{
${ }^{1}$ Centre for Australian Forensic Soil Science (CAFSS); Vice chair, International Union of Geological Sciences, Initiative on Forensic \\ Geology (IUGS-IFG); *Corresponding author,E-mail: rob.fitzpatrick@csiro.au \\ ${ }^{2}$ CSIRO Land and Water, Waite Campus Locked Bag 2, Urrbrae, South Australia, 5064
}

(Received: February 27, 2017; Revised accepted: March 16, 2017)

http://dx.doi.org/10.18814/epiiugs/2017/v40i2/017017

Through five diverse cases involving an attempt of murder, cold murder in 1988, two contemporary murder investigations in the past 10 years and sexual assault, this paper will demonstrate how combined pedological, mineralogical and chemical investigations, have been critical in developing reliable soil information, from landscape to microscopic scales, to help in forensic investigations, which were used as evidence in Australian State Supreme courts. A wide range of natural soil types (sandy coastal beaches, grey clayey wetlands, black muddy alluvium in river-beds, brown clayey and loamy soils in wooded areas) and humanmade soil types (comprising brick and road gravel fragments) across Australia were used in these forensic investigations to associate materials taken from questioned items, such as shoes, clothing, shovels or vehicles, with a specific control location or the crime scene. To illustrate the power of soil analysis in criminal investigations it is beneficial to share successful case examples to demonstrate the potential value of this somewhat under-utilized forensic tool. Here we will discuss how pedological and soil mineralogy expertise, especially in using soil maps and $X$-ray diffraction (XRD), has been used as a contributory part of each overall historical (cold) and recent criminal investigation.

\section{Introduction}

Soil can be used to indicate or compare provenance, and therefore be used as intelligence and subsequently evidence to narrow areas of search during an investigation. Evaluative comparison of soil on one article of evidence compared to another, or compared to a known location, can and has been used as evidence in courts of law (e.g., Pye, 2007; Ritz et al., 2008; Ruffell and McKinley, 2008; Fitzpatrick et al., 2009; Murray, 2011; Fitzpatrick and Raven, 2012; Fitzpatrick, 2013a, b).

Earth materials such as soils, rocks, minerals and human-made mineral particles like bricks provide excellent evidence to link criminals to crime scenes. Forensic earth scientists such as soil scientists and geologists are now also using advanced automated techniques, which have the ability to acquire information from smaller samples to make earth forensics an increasingly popular tool in criminal investigations. The aim of soil forensic analysis is to associate soil, rock or mineral samples taken from questioned items, such as shoes, clothing, shovels or vehicles, with a specific control location or the crime scene. Earth materials are powerful, perhaps ideal, pieces of contact trace evidence that help in criminal investigations for the following reasons as outlined by Fitzpatrick (2013a, b):

Soils are highly individualistic in that there are an almost infinite number of different types; soils change rapidly over very short distances both horizontally and vertically, enabling soil forensic examiners to distinguish between soil material samples. The human-made or anthropogenic properties (e.g., additions of brick or glass fragments) make the naturally occurring soils even more individualistic.

Fine clayey mud and fine sand size fractions of soils have a strong capacity to transfer and stick onto shoes or clothing.

Unlike the more obvious bright transfer colours of blood, lipstick smears and paint, soil materials are nearly invisible. Fine soil materials, especially when they impregnate vehicle carpeting, shoes or clothing, are often not visible to the naked eye; a suspect will often make little effort to remove them.

Soil materials are easily located and collected using hand lenses or light microscopes when inspecting crime scenes or examining evidence.

Soil materials are easily described and characterized by colour and by using various analytical methods such as x-ray diffraction (mineralogy) and spectroscopy (chemistry). For example, the colour of a soil indicates its origin as well as the compounds present in the soil. White or grey soil may contain lime or have been leached, while black or grey soil indicates the soil contains organic materials and moisture respectively. Red, brown or yellow soil usually indicates the presence of iron compounds.

Digitized soil maps and soil profile databases can be readily accessed by police or forensic scientists through the web, e.g., Australian Soil Resources Information System (ASRIS) database (Johnston et al., 2003).

This paper will demonstrate how pedological (field work and soil/ geological maps) and laboratory approaches especially, involving traditional and synchrotron X-ray diffraction (XRD) methods have been critical in developing predictive, soil-regolith models, from microscopic 
to landscape scales, to assist soil/geological-based criminal investigations. To illustrate the power of soil and geological analysis in criminal investigations it is beneficial to share successful case examples to demonstrate the value of this somewhat under-utilized forensic tool as indicated in the 5 diverse case studies/murder investigations, which are briefly summarised in this paper.

\section{Approaches and Methods}

The Centre for Australian Forensic Soil Science (CAFSS) staff members are regularly subpoenaed to testify in court. To meet these responsibilities CAFSS have developed Guidelines for Conducting Criminal and Environmental Soil Forensic Investigations (Fitzpatrick and Raven, 2016). The guidelines provide a systematic approach and use of appropriate standard methods for sampling, characterizing and examining soils for forensic comparisons. Forensic soil characterization requires a multidisciplinary approach, combining pedological (descriptive and spatial information) and analytical (mineralogical and chemical) information. They also assist CAFSS in its mission by ensuring efficiency and accountability in the proper handling, storage and tracking of soil evidence, which is essential to evidence collection and ultimately prosecution.

When examining soil evidence, there are a range of stages involving screening soil tests (Stage 1) that help provide pieces of a puzzle and then more detailed tests (stages 2 and 3), which will assist in providing more reliable answers. Comparing soils is no easy task, especially if the questioned samples are very small submillimetre particles (less than $0.5 \mathrm{~mm}$ diameter in size, and weighing less than a milligram) and if they comprise polycrystalline minerals (e.g., cristobalite and mullite), such as in small brick particles that have been made by the firing of earth materials at high temperatures. In addition, forensic materials may contain trace amounts of mineral particles, such as rutile or anatase within small paint or plastic flecks. Traditional X-ray diffraction (XRD) techniques using low-background Si wafer holders are useful for measuring XRD patterns from samples with weights as low as several milligrams. However, these techniques are generally too insensitive to measure XRD patterns from samples weighing less than a milligram or comprising submillimetre particles. The mineralogy of small fragments $(<0.5 \mathrm{~mm})$ can be determined with micro-XRD techniques using fine (submillimetre) monocapillary attachments on laboratory XRD instruments. While these instruments are adequate for determining dominant components, synchrotron XRD with high $\mathrm{X}$-ray intensity provides far greater sensitivity and resolution than laboratory source XRD systems. This enables identification of minute amounts of mineral components.

\section{Case Study 1: Soil as Evidence in a Sexual Assault Case in Adelaide, South Australia}

This investigation highlights the critical importance of: (i) consulting soil maps to determine the degree of soil spatial variability between locations to be compared (crime scenes, suspect's home and victim's home), (ii) detailed pedological sampling of soils from a range of likely reference and alibi sites and (iii) detailed X-ray diffrac- tion analyses to identify the presence of unusual minerals (i.e., in this case study, at a specific location on the footpath outside the victim's home, road metal containing dolomite had become mixed with the common soil underlying the entire crime investigation area, which was remarkably similar to soil on the suspect's shoes).

\section{Stage 1: Background}

In November 2007, a 10 year old girl was kidnapped in her Paralowie home in South Australia and sexually assaulted by a male in the nearby school grounds at two locations only $300 \mathrm{~m}$ and $500 \mathrm{~m}$ from her home (Figs. 1 and 2). The suspect was caught after using a credit card he stole from the victim's house. Shoes were collected from the suspect's residence, which is within $500 \mathrm{~m}$ of the victim's home and the school. The suspect denied any contact with the victim or with the crime scenes. The whole area is residential, except for the school grounds, which has un-grassed playing fields and adjacent woodlands (i.e., where the victim was sexually assaulted twice). In this residential scene of crime area only two control samples were collected by Crime Scene Investigators (CSI) near where the victim was sexually assaulted.

Initial analysis of these CSI-sampled soils using soil morphology, microscopical and X-ray diffraction methods, indicated that the control soil samples and questioned soils on the suspect's shoes "appeared similar" (i.e., have a moderate "degree of comparability" of being from a single location). However, after consulting a soil map of the whole residential scene of crime area (Northcote et al., 1960-68), it was established that the school grounds and adjacent residential area are underlain by a common soil type, which is classified as Red-Brown Earths by Northcote et al. (1960-68); and as Calcaric Red Chromosols and Calcic Palexeralfs in accordance with the Australian Soil Classification (Isbell and National Committee on Soils \& Terrain, 2016) and Soil Taxonomy (Soil Survey Staff, 2014) respectively. Based on this information and the limited number of CSI-sampled soils, it would have been difficult to confirm if the questioned soil on the suspect's shoes originated from the crime scene, suspect's/victim's homes or at any other locality within the residential scene of crime area. This preliminarily soil evaluation could not stand the test of a law courts examination because it was based on insufficient detailed site investigations and numbers of samples.

As a consequence, the area was revisited in February 2008 by forensic soil scientists to determine the degree of soil spatial variability at all locations that should be compared. Additional control $(2$ crime scenes) and alibi/reference (9 likely sites near the victim's and suspect's houses) samples were collected to better reflect the spatial variability of soil types (i.e., underlying "natural soils" and "human-made soils" in back/front yards of homes, pavement areas and footpaths) at the various locations to determine with more confidence differences or similarities between the control, alibi, reference and questioned samples (Fig. 1).

\section{Stages 2 and 3: Detailed Characterization}

Detailed characterisation and quantification of composite and individual soil particles (Stages 2 and 3 ) is conducted after sample selection (i.e., nine samples, Table 1$)$ and size fractionation ( $<50$ microns) 


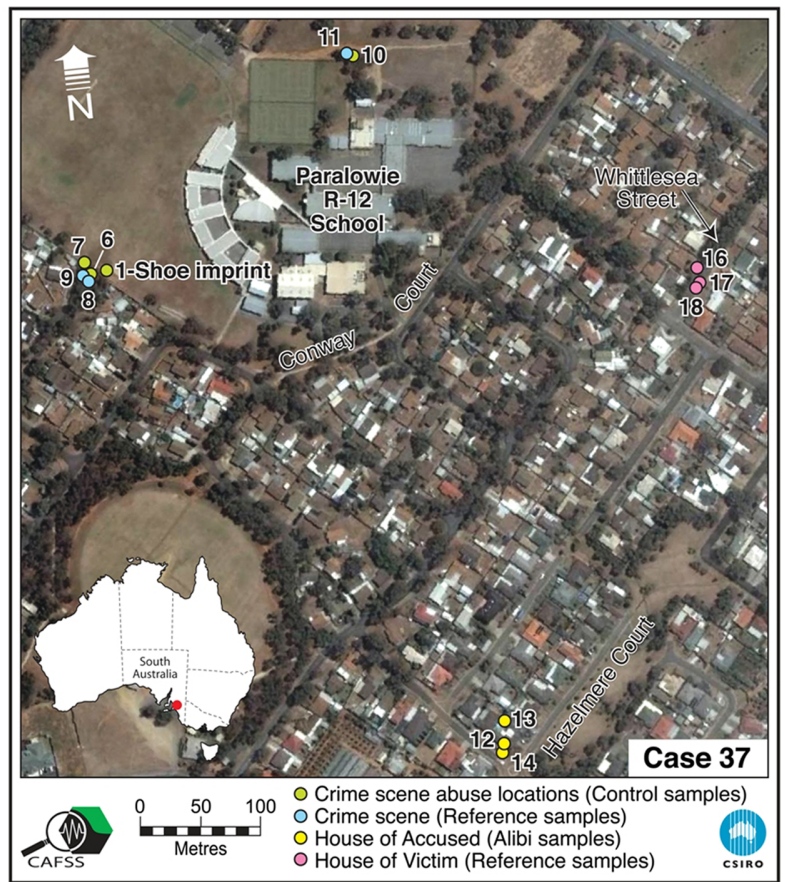

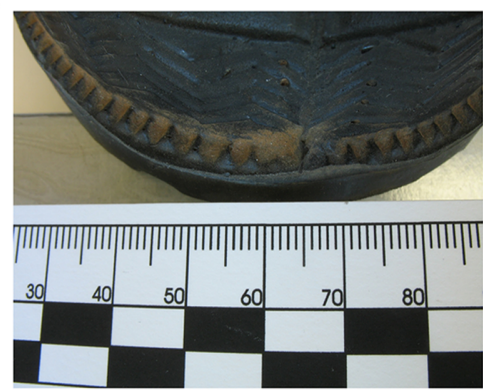

(a)

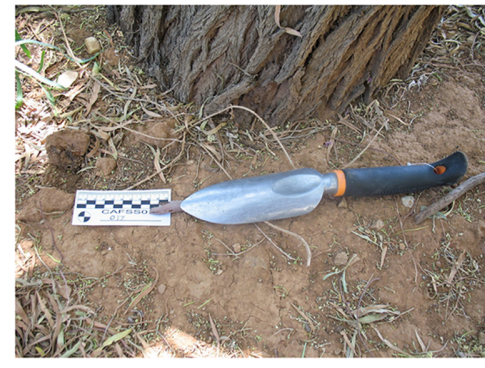

(b)

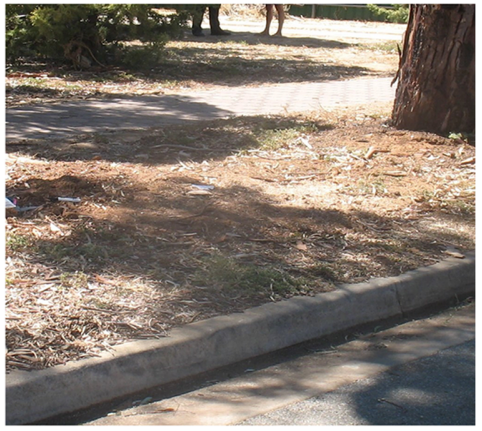

(c)

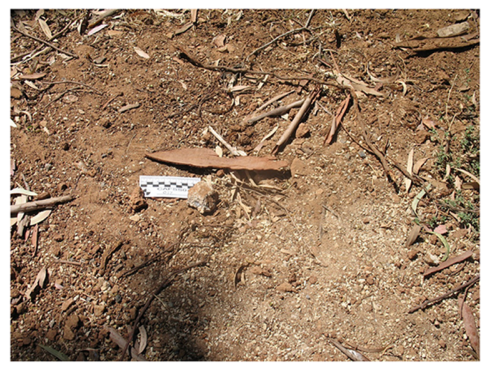

(d)

Figure 1. Google Earth image showing thirteen localities where soil materials were sampled at: (i) Crime scene abuse locations (Control sites), (ii) locations nearby to crime scenes (Reference sites where samples of loose-possibly transferable soil taken in pathways and under trees), (iii) suspect's house (Alibi sites where samples were collected on the surface (0 to $3 \mathrm{~cm}$ ) and (iv) victim's house (Reference sites). Additional samples were collected to determine whether or not the accused had transferred soil materials to his shoes from near his house or near the house of the victim or near/at the crime scenes. The photographs from top to bottom are of: (a) top of rubber shoe sole with tooth-like edge moulding from accused shoe showing brown (7.5YR4/4 moist) clayey soil (Questioned soil; CAFSS_037.4), (b) brown (7.5YR4/4 moist) clayey soil in the wooded area at crime scene (Control soil sample CAFSS_037.7), (c and d) reddish brown clayey soil with white quartz and dolomite gravel (Reference soil sample, CAFSS_037.16) from the road-verge at victim's house (from Fitzpatrick and Raven, 2009).

using mainly X-ray powder diffraction (XRD) methods, which are effective for determining both qualitative and quantitative mineral analyses of solid materials in forensic soil science.

\section{Stage 4: Integration and Extrapolation of Soil Information from One Scale to Next}

Sufficient descriptive and mineralogical (XRD) data was acquired on all soil samples to determine the major similarities and differences between the samples using "Categories of Comparability" as defined by Fitzpatrick and Raven (2016). We established the "degree of comparability" of the soil materials from the shoes (two samples) being "comparable" or "not comparable" to the 15 representative control and alibi soil samples.

The brown (7.5YR 4/4) clayey soil on the top of the sole of the shoes had markedly similar soil morphological properties (soil colour and texture) and mineralogy (i.e., all nine minerals identified have similar composition and crystallinity: quartz, albite, orthoclase, mica, kaolin, calcite, chlorite, hematite and dolomite (and does not contain amphibole) (Table 1). The fine detail expressed in the XRD patterns from these two soil samples are remarkably similar as shown in Figure 2. The brown (7.5YR 4/4) clayey soils found at the two control sites (i.e., sexual abuse locations in the Paralowie school grounds) also had similar soil morphological properties (soil colour and texture) and mineralogy (quartz, albite, orthoclase, mica, kaolin, calcite, amphibole and hematite; both do not contain dolomite) to the soils found on the bottom of the sole and top of the sole of the shoes.

The soil recovered from the top of the sole of the shoe (questioned sample) has: (1) an extremely strong degree of comparability to the reference soil sample taken from near the victim's house between the foot path and road (CAFSS_037.16); (2) a moderately strong degree of comparability to the 4 control sites (i.e., sexual abuse locations) on the Paralowie school oval (CAFSS_037.1;2) and nearby wooded areas (CAFSS_037.7; 10) and (3) a moderate degree of comparability to the sandy clay loam alibi soil material recovered from the back yard of the accused's house (CAFSS_037.12).

In summary, the reference "human-made soil" taken from near the victim's house between the foot path and road (CAFSS_037.16) differed in containing dolomite compared to other control and alibi soils, which also had reddish-brown colours and were clayey (i.e., control samples from the Paralowie School and an alibi sample from the accused back yard). The occurrence of dolomite supported the interpretation that this reference "human-made soil" and the soil on the top of the sole of the shoe had very likely originated from a specific location on the footpath at the victim's house where the natural reddish brown clayey soil and dolomite-rich road metal had mixed to form a distinctive "human-made soil".

The evidential significance of the shoe deposit aided in the police investigation and led to the accused confessing to abducting the 10 year old child from her house and raping her. On $16^{\text {th }}$ July 2009, he was sentenced to a non-parole term of seven years. 
Table 1. Summary of mineralogical composition from XRD analysis for samples with similar morphological properties

\begin{tabular}{|c|c|c|c|c|c|c|c|c|c|c|}
\hline CAFSS (IDENT and description) & Q & Alb & Oth & Mi & $\mathrm{Kt}$ & Chl & $\mathrm{Am}$ & $\mathrm{Ct}$ & $\mathrm{Dt}$ & $\mathrm{Ht}$ \\
\hline 037.1 Paralowie school, surface ${ }^{(2)}$ & $\mathrm{D}$ & M & $\mathrm{T}$ & $\mathrm{T}$ & $\mathrm{T}$ & $\mathrm{T}$ & $\mathrm{T}$ & $\mathrm{T}$ & - & $\mathrm{T}$ \\
\hline 037.2 Paralowie school, subsoil ${ }^{(2)}$ & $\mathrm{D}$ & M & $\mathrm{T}$ & $\mathrm{T}$ & $\mathrm{T}$ & $\mathrm{T}$ & $\mathrm{T}$ & $\mathrm{T}$ & - & $\mathrm{T}$ \\
\hline 037.3 Bottom of sole ${ }^{(1)}$ & $\mathrm{D}$ & M & $\mathrm{T}$ & $\mathrm{T}$ & $\mathrm{T}$ & $\mathrm{T}$ & - & M & - & $\mathrm{T}$ \\
\hline 037.4 Top of sole ${ }^{(1)}$ & $\mathrm{D}$ & M & M & M & $\mathrm{T}$ & $\mathrm{T}$ & - & $\mathrm{T}$ & $\mathrm{T}$ & $\mathrm{T}$ \\
\hline 037.5 Nodule from $037.2^{(2)}$ & $\mathrm{CD}$ & $\mathrm{T}$ & $\mathrm{T}$ & $\mathrm{T}$ & $\mathrm{T}$ & $\mathrm{T}$ & - & $\mathrm{CD}$ & - & $\mathrm{T}$ \\
\hline 037.7 Paralowie school, nearby park $^{(2)}$ & $\mathrm{D}$ & M & $\mathrm{T}$ & $\mathrm{T}$ & $\mathrm{T}$ & $\mathrm{T}$ & $\mathrm{T}$ & $\mathrm{T}$ & - & $\mathrm{T}$ \\
\hline 037.10 Paralowie school, surface ${ }^{(2)}$ & $\mathrm{D}$ & M & $\mathrm{T}$ & $\mathrm{T}$ & $\mathrm{T}$ & $\mathrm{T}$ & $\mathrm{T}$ & $\mathrm{T}$ & - & $\mathrm{T}$ \\
\hline 037.12 Accused home back yard ${ }^{(3)}$ & $\mathrm{D}$ & M & $\mathrm{T}$ & $\mathrm{T}$ & $\mathrm{T}$ & - & $\mathrm{T}$ & $\mathrm{T}$ & - & $\mathrm{T}$ \\
\hline 037.16 Victim's home footpath ${ }^{(4)}$ & $\mathrm{D}$ & $\mathrm{M}$ & $\mathrm{T}$ & $\mathrm{T}$ & $\mathrm{T}$ & $\mathrm{T}$ & - & $\mathrm{T}$ & $\mathrm{T}$ & $\mathrm{T}$ \\
\hline
\end{tabular}

${ }^{(1)}$ Questioned shoe samples (CAFSS_037.3 and CAFSS_037.4) were not sieved because they are approximately $<50$ micron.

${ }^{(2)}$ Control samples (Paralowie school) were sieved $(<50$ micron fraction).

${ }^{(3)}$ Alibi samples were sieved $(<50$ micron fraction).

${ }^{(4)}$ Reference samples were sieved ( $<50$ micron fraction).

$\mathrm{Q}=$ Quartz; Alb = Albite; Oth = Orthoclase; $\mathrm{Mi}=$ Mica; $\mathrm{Kt}=$ Kaolin; $\mathrm{Chl}=$ Chlorite; $\mathrm{Am}=$ Amphibole; $\mathrm{Ct}=\mathrm{Calcite} ; \mathrm{Dt}=\mathrm{Dolomite} ; \mathrm{Ht}=\mathrm{Hematite}$.

D: Dominant ( $>60 \%)$, CD: Co-dominant, SD: Sub-dominant (20\% to $60 \%)$, M: Minor (5\% to $20 \%)$, T: Trace $(<5 \%)$.

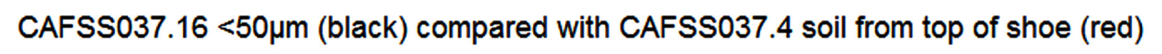

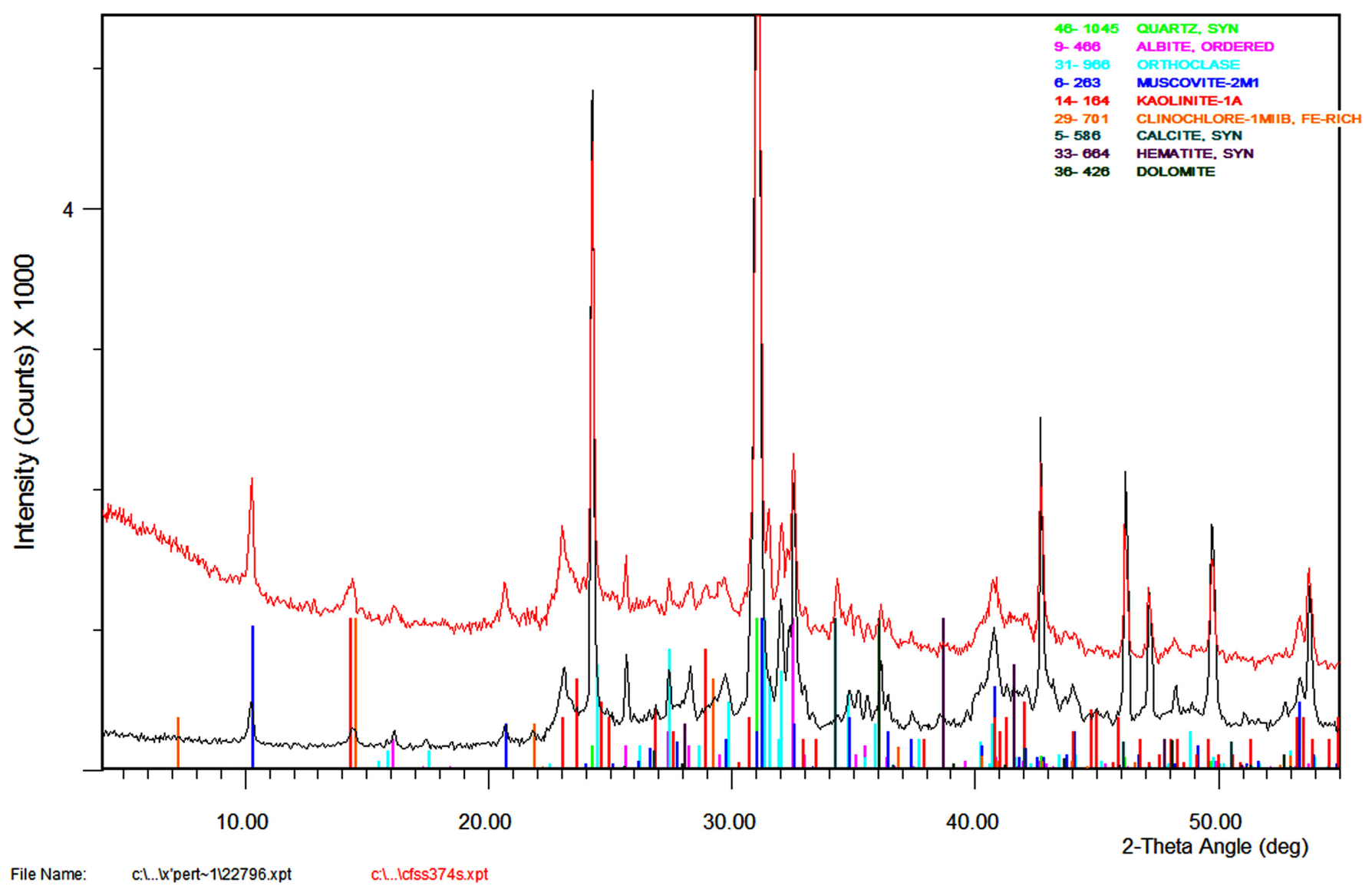

Figure 2. Comparison between X-ray diffraction (XRD) patterns of the questioned soil sample from the top of the right shoe sole (CAFSS_037.4) (red) and the reddish clayey alibi soil between road and footpath at victim's home (CAFSS_037.16) (<50 micron fraction) (black). Samples were both ground using an agate mortar and pestle before being lightly pressed into aluminium sample holders for XRD analysis. XRD patterns were recorded with a Philips PW1800 microprocessor controlled diffractometer using CoK $\alpha$ radiation, variable divergence slit and graphite monochromators. 


\section{Case Study 2: Body in Clayey Wetland (Cold Case) - Sydney, New South Wales}

The body of a drowned teenage girl (Janine Balding) was located by police in a wetland in 1988 but no suitable soil samples were analyzed. A suspect's tracksuit pants (Figs. 3 and 4) and shoes, which were kept by police since 1988, were re-examined by forensic soil scientists in 2005 (17 years later) to show traces of grey and yellowish clayey soil (Figs. 3 and 4).
These soil traces were removed and characterized by Fitzpatrick et al. (2007). Samples of clayey grey soil from within the wetland and yellowish soil on the fringe were sampled in 2005. The morphology and mineralogy from XRD analyses (Fig. 4) of the two control samples taken from the suspects clothing were similar to the two samples from the wetland area - despite being sampled 17 years later. The soil and clay mineralogy evidence described in Fitzpatrick et al. (2007), indicated that the suspect had been present at the site where the victim drowned.

\section{SOIL ON CLOTHING - MURDER CASE}

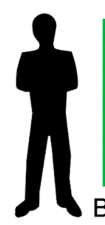
teenager located in wetland. Police arrest suspect and impound clothing as evidence to be closely examined.

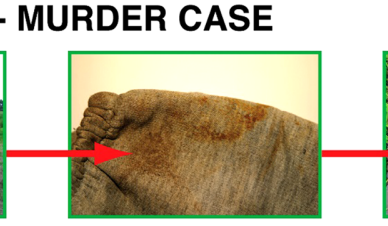

Suspect's tracksuit pants show traces of 2 different soils but police cannot positively relate them to the wetland area where the body was found.
SOIL FORENSICS

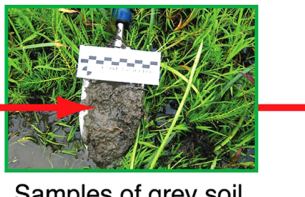

Samples of grey soil from within the wetland, and yellow soil on fringe, are taken to laboratory for detailed inspection and analysis.
RESULTS OF INVESTIGATION

Soil evidence gathered indicated that the suspect had been present at the site where the victim drowned.

The morphology (colour) and mineralogy of the 2 samples taken from the

suspects clothing are

similar to the 2 samples taken from the wetland area.

Figure 3. Summary of soil evidence relating to the Janine Balding case, which involved re-sampling and investigating soil on a suspect's tracksuit pants (and shoes) and soils from within and on the edge of a wetland where Janine Balding's body was located by police in 1988.

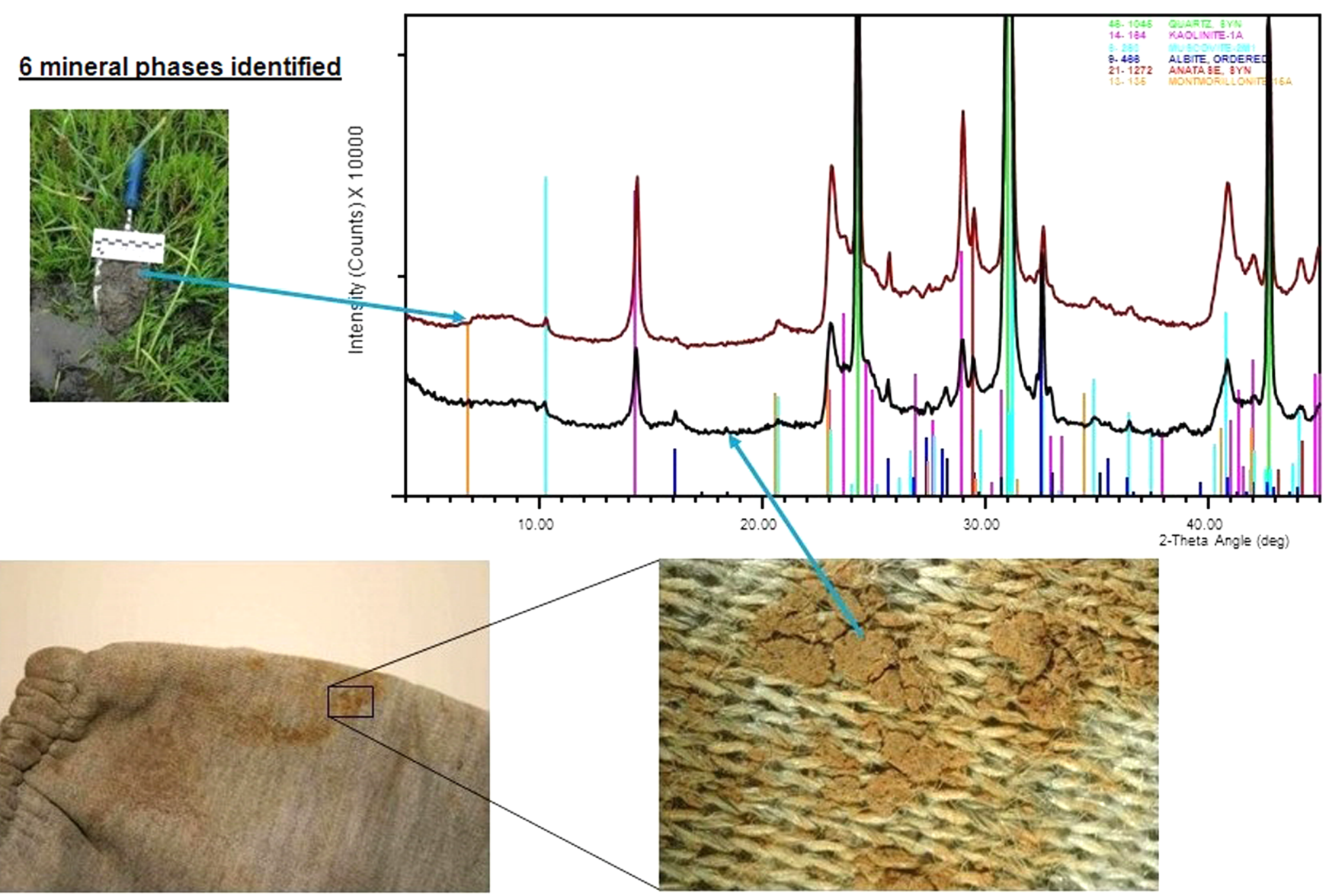

Strong degree of comparability

Figure 4. Comparison between X-ray diffraction (XRD) patterns of the yellow brown questioned soil sample from the suspect's tracksuit pants (bottom photographs) and clayey yellowish soil on the fringe of the wetland, which was re-sampled in 2005 (from Fitzpatrick et al., 2007). 


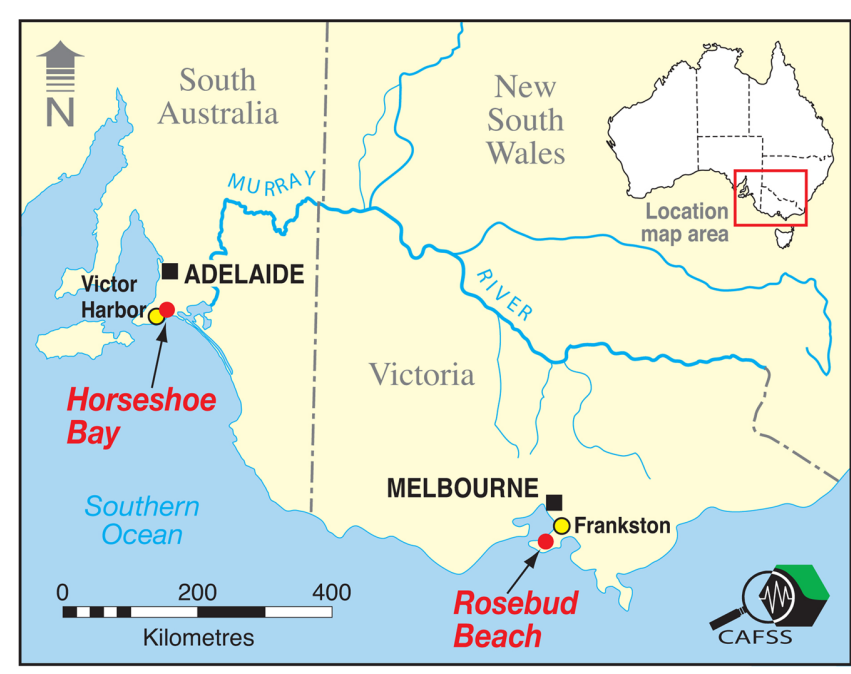

Figure 5. Locality of beach (crime scene) at Horseshoe Bay (Lady Beach as shown in Fig. 6) in South Australia where teenage girl Carly Ryan's body was located in shallow water on the beach and the locality of the beach (Rosebud Beach) in Victoria where police located two pairs of shoes from both suspects (e.g., see photograph of one shoe in Fig. 6), which contained large amounts of sandy soil material adhering and coating/surrounding the insole within both shoes.

\section{Case Study 3: Body on Sandy Beach - South Australia and Victoria}

A teenage girl's body (Carly Ryan) was located in shallow water on a beach (crime scene) in South Australia (Fig. 5). Police located shoes from two suspects on a beach in Victoria, which is approximately $1000 \mathrm{~km}$ from the crime scene (Fig. 5). The morphology (colour, presence of shiny tan-coloured particles, size, shape) of the sand grains and mineralogy of shell fragments from XRD analyses (aragonite, calcite, Mg-substituted calcite, goethite, and quartz) of the samples taken from the inner soles in the shoes of both suspects were similar to beach samples at the crime scene on Lady Beach, South Australia (Fitzpatrick and Raven, 2008). Equally, they do not resemble the morphology and mineralogy of sand samples collected from Rosebud Beach in Victoria where the shoes were retrieved by police. The soil and mineralogy evidence gathered indicated that both suspects were present at the crime scene. One individual was found guilty of murder by a jury and sentenced to life imprisonment with a non-parole term of 29 years.

\section{Case Study 4: Clay Soils on Shoes and Clothing: Attempted Murder and Kidnapping in Mel- bourne, Victoria}

Pedological and X-ray diffraction analysis provided morphological and mineralogical information on the nature and properties of soils: (i) located in the treads of the suspects shoes, which had been washed in a washing machine (Fig. 7), (ii) the known soils at the crime scene and (iii) from the victims clothing/shoes (Fig. 7). All samples contained quartz, andesine/anorthite, mica, kaolin, smectite, hematite, pyroxene (augite), ilmenite and anatase in similar amounts as shown Figure 8 (Fitzpatrick and Raven, 2010). In addition, the fine detail expressed in the XRD patterns of the soil samples from suspect's shoes (questioned sample) and the muddy river bank (known crime scene) are remarkably similar as shown in Figure 8. However, the victim's shoes (CAFSS 056.4: runners) also contained a trace amount of dolomite, which likely accumulated on the runners from a previous and/or subsequent activity).

In summary, the directed sampling of clayey soil in the muddy river-bed area of the crime scene where there was an attempted murder (stabbing and drowning), followed by definitive pedological and soil characterization using X-ray diffraction, indicated that the soil morphology and clay mineralogy showed major similarities and differences between samples. It was established that there was a "very strong degree of comparability" of the soil materials from the clothing (three samples) and shoes (three samples) with the soil sample from the crime scene, confirming all suspects were present at the crime scene. Two persons were found guilty of attempted murder and kidnapping by a jury.

\section{Case Study 5: Small Brick Fragments on Clothing: Rayney Murder Case - Perth, Western Australia}

This case represents the first successful development and application of a new advanced laboratory source and synchrotron XRD technique to identify and quantify the mineralogy of polycrystalline minerals

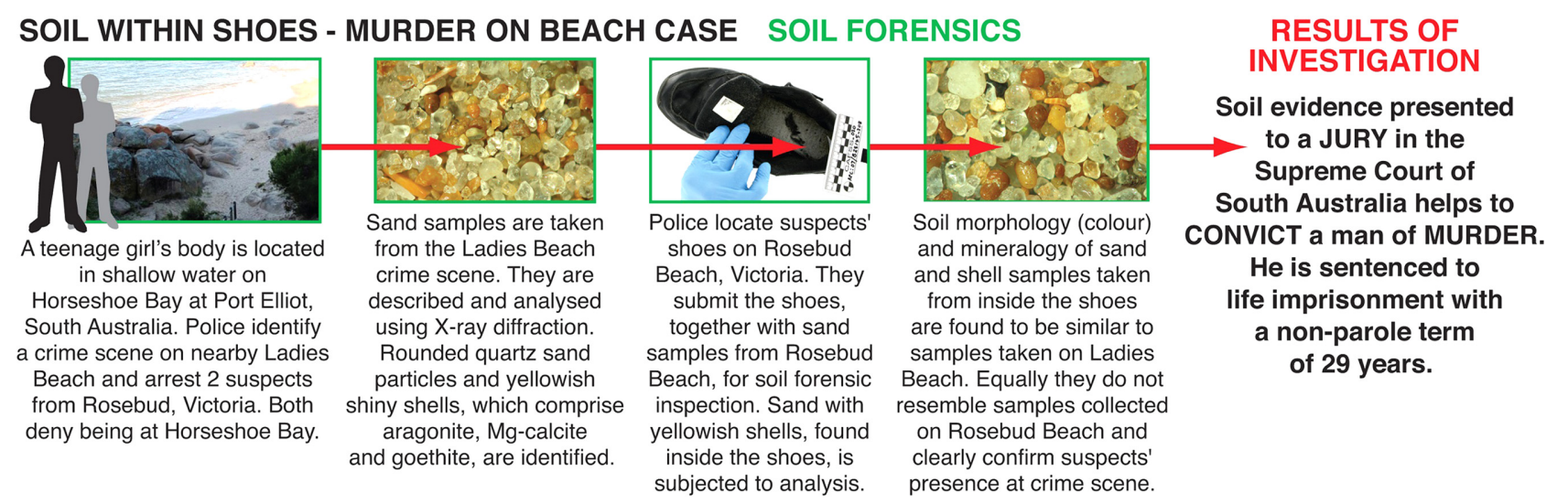

Figure 6. Summary of soil evidence relating to the Carly Ryan murder case, which involved the location of Carly Ryan's body in shallow water on a beach (crime scene) in South Australia and the suspects shoes located on Rosebud Beach, Victoria. 

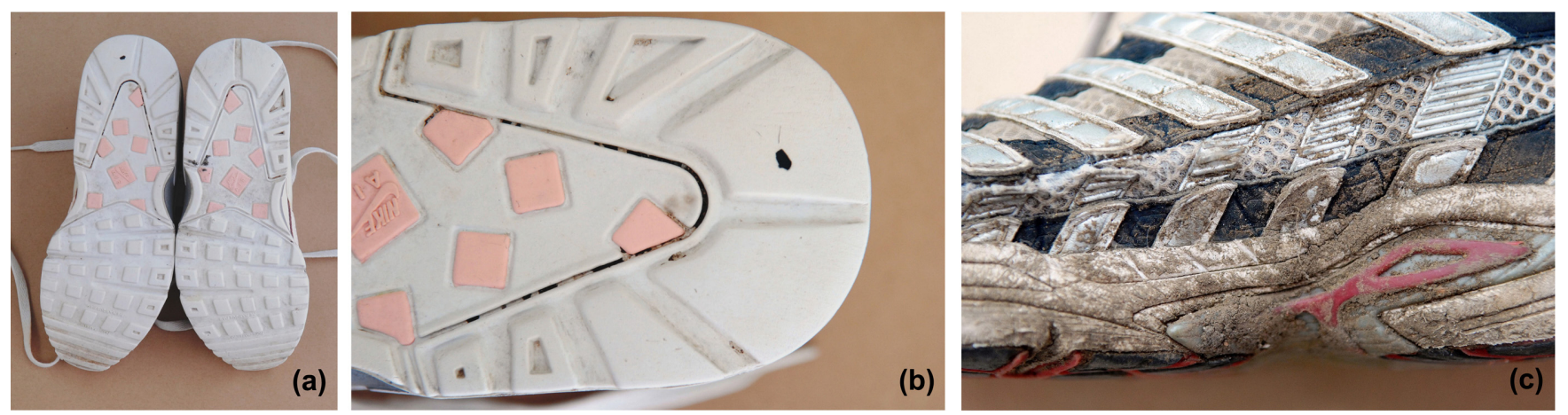

Figure 7. Photographs of the suspect's shoes/white pink runners showing small amounts of soil in the treads of the shoes, which had been washed in a washing machine (a and b) and the victim's shoes/runners (c: CAFSS_056.4) showing large amounts of soil (from Fitzpatrick and Raven 2010).

Comparison of $<50 \mu \mathrm{m}$ fraction of CAFSS056.7 (black) and bulk sample of CAFSS056.3 (red)

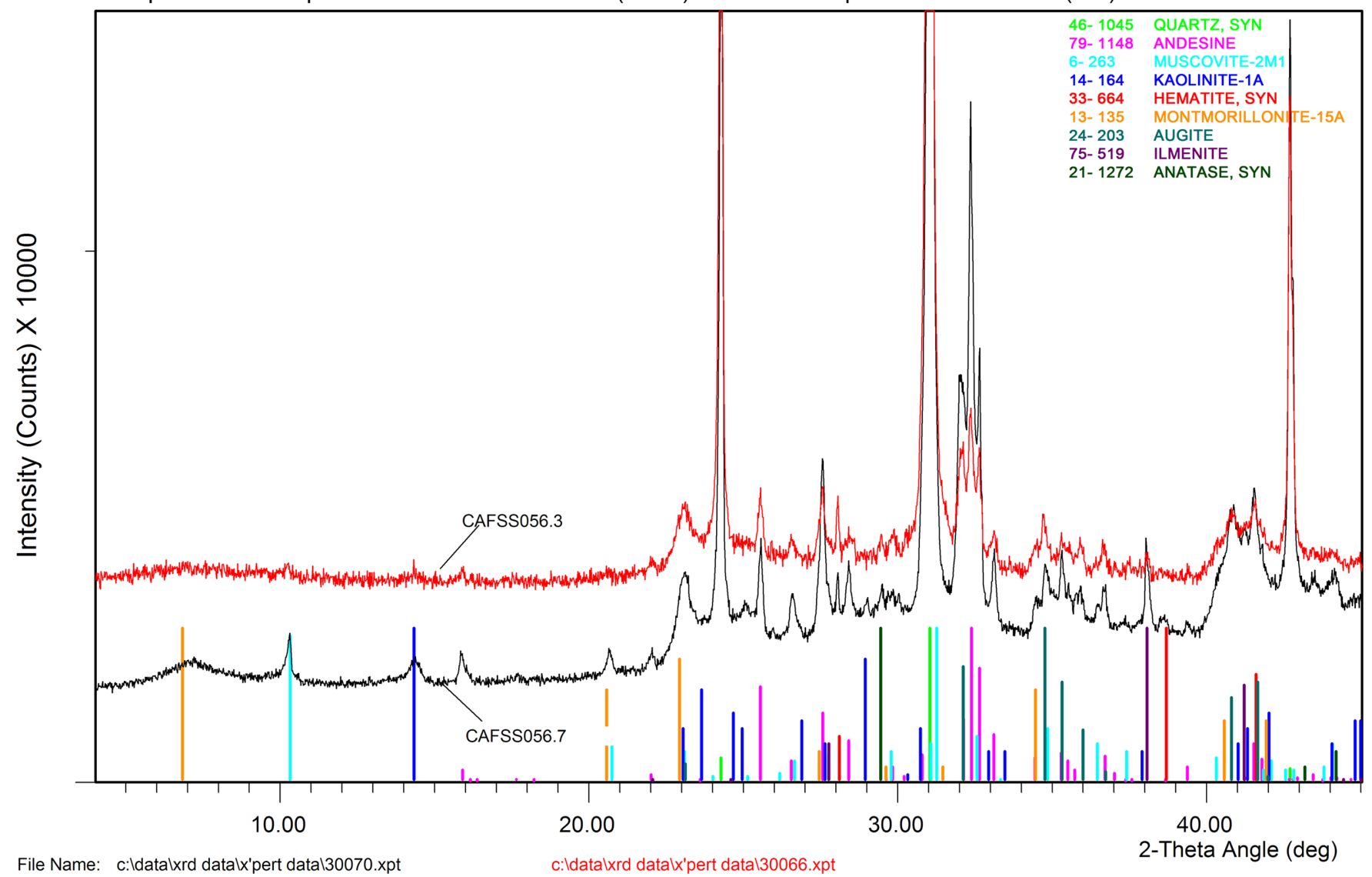

Figure 8. Comparison between X-ray diffraction (XRD) patterns of soil samples collected from: (i) treads of the suspect's shoes (shown in Fig. 7), which had been washed in a washing machine (red: CAFSS_065.3) and (ii) the muddy river bank crime scene (black: CAFSS_065.7) (from Fitzpatrick and Raven, 2010).

(e.g., cristobalite and mullite) in soils and small submillimetre brick particles $(<0.5 \mathrm{~mm}$ diameter) on questioned clothing (bra), hair and seed pods in the Rayney homicide case in Perth to establish the origin of the small submillimetre brick particles (Fitzpatrick et al., 2011).

\section{Stage 1: Background}

On August 7th 2007, Corryn Rayney, a Supreme Court registrar, failed to return home after a boot scooting dancing class at a nearby Community Centre in Bentley, a suburb of Perth, Western Australia. Her body was subsequently recovered on August $16^{\text {th }} 2007$ after transmission oil from her broken down, abandoned car lead police to a clandestine gravesite along a dirt track in Kings Park, also located in Perth.

Stage 1: Initial Location and Characterization of Brick Particles and Soils

Soil evidence from the victim's body, clothing, home, vehicle, Community Centre and grave site were analysed extensively in order to identify the likely movement of the victim after she left the Com- 
munity Centre. The Perth coastal plain consists of predominantly coarse sandy soils, which show minor mineralogical variation throughout the region and consequently pedology and bulk soil mineralogy was of little use. However very small (often $<0.5 \mathrm{~mm}$ ) red particles were observed on the victim's body, clothing (mainly her bra), home and vehicle. These red particles were not found at the Community Centre or the surrounds of the gravesite.

Recycled red house bricks were extensively used at the victim's home for paving of the driveway, footpaths and pergola area. The bricks were recycled from houses constructed prior to the 1940's when weaker lime mortar was replaced with stronger Portland cement mortars. Bricks manufacture prior to 1940 were sourced from several localities and the bricks subjected to less than ideal firing conditions. The red bricks used at the victim's home therefore ranged in hardness and durability from soft to very hard, in contrast to the yellow/pale-brown bricks from the Community Centre, which were very hard.

\section{Stages 2 and 3: Detailed Characterization using X-ray Diffraction}

Laboratory X-ray Diffraction (XRD) analysis of 42 bricks from the victim's home and the Community Centre confirmed mineralogy could classify the bricks into 5 or 6 distinct groups (Fitzpatrick et al., 2011; Raven et al., 2016). Powdered bulk and small fragments extracted from the 42 bricks were measured on the Powder Diffraction beamline at the Australian Synchrotron. The Synchrotron results showed that each of the small brick fragments examined could be effectively matched to the whole brick group from which the fragment originated. Fragments of red particles from the forensic evidence were subsequently analysed at the Synchrotron and were shown to be consistent with having originated from the victim's home - even to one specific type of brick.

\section{Stage 4: Integration and Extrapolation of Brick Particles and Soil Information from One Scale to Next}

The CAFSS report and presentations/cross examination in the Perth Supreme court provided a "predictive, soil-regolith model, from microscopic to landscape scale", which established that soil and brick particles/fragments found on the victims bra and hair (via two seed pods) originated from the front yard of the victims home at Como in Perth.

The trial was before a judge only and he concluded that the mineralogy data from the brick particles on the victim's clothing and the bricks from her front driveway suggested she was initially attacked in her front yard and not at Kings Park where her body was buried (Martin, 2012).

\section{Summary and Future Challenges}

The strength of soil forensic evidence is becoming increasingly well accepted. In fact, five cases in Australia have been conducted where the suspect has decided to admit guilt without forensic work actually being carried out. Detectives have simply told suspects or their legal teams that soil samples have been or will be collected for investigation and comparison by forensic soil scientists.
The work can often be painstaking. For example, in the complex Rayney Murder case (Case Study 5) the CAFSS team spent two years successfully linking minute brick particles in a murder victim's bra and hair to a collection of old brick pavers in the front yard of the victim's home - even to one specific type of brick.

\section{Acknowledgements}

The authors would like to thank Greg Rinder for art and graphics work in Figures 1, 3, 5, and 6. We thank Dr. Duncan Pirrie for constructive comments on the draft manuscript.

\section{References}

Fitzpatrick, R.W., 2013a, Soils. in Siegel, J.A., and Saukko, P.J. (eds.), Encyclopedia of forensic sciences ( $2^{\text {nd }}$ edition): Academic Press, Waltham, pp. 206-212.

Fitzpatrick, R.W., 2013b, Soil: forensic analysis. in Jamieson, A., and Moenssens, A., (eds.), Wiley encyclopedia of forensic science: John Wiley \& Sons, Ltd., The Atrium, Southern Gate, Chichester, West Sussex, PO19 8SQ. http://dx.doi.org/10.1002/9780470061589.fsa096.pub2 (August 2013 updated articles).

Fitzpatrick, R.W., Raven, M.D., and Forrester, S.T., 2009, A systematic approach to soil forensics: criminal case studies involving transference from crime scene to forensic evidence. in Ritz, K., Dawson L., and Miller, D. (eds.), Criminal and environmental soil forensics: Springer Science+Business Media B.V., pp. 105-127.

Fitzpatrick, R.W., and Raven M.D., 2008, Investigation to determine if shoes and jeans submitted by South Australian Police contain soil materials that compare with control soil samples from Rosebud beach in Victoria and Horseshoe Bay in South Australia: Centre for Australian Forensic Soil Science, Restricted Client Report No. CAFSS_030, June 2008, 49 p.

Fitzpatrick, R.W., and Raven M.D., 2009, Investigation to determine if shoes submitted by South Australia Police contain soil materials that are comparable with soil samples from thirteen sites: Centre for Australian Forensic Soil Science, Restricted Client Report No. CAFSS_037, June 2009,46 p.

Fitzpatrick, R.W., and Raven M.D., 2010, Investigation to determine if soil collected from clothing and shoes (runners) submitted by the Victorian Police contain soil materials that are comparable with a soil sample from the crime scene: Centre for Australian Forensic Soil Science, Restricted Client Report No. CAFSS_056, February 2010, 33 p.

Fitzpatrick, R.W., and Raven, M.D., 2012, How pedology and mineralogy helped solve a double murder case: Using forensics to inspire future generations of soil scientists: Soil Horizons, v. 53, no. 5, pp. 14-29.

Fitzpatrick, R.W., and Raven, M.D., 2016, Guidelines for conducting criminal and environmental soil forensic investigations (Version 10.1): Centre for Australian Forensic Soil Science, Report No. CAFSS_076, $46 \mathrm{p}$.

Fitzpatrick, R.W., Raven, M.D., and Self, P.G., 2011, Detailed mineralogical characterization of small brick and soil fragments $(<0.5 \mathrm{~mm}$ diameter) by Synchrotron X-ray diffraction analyses for further forensic comparisons relating to Operation Dargan: Centre for Australian Forensic Soil Science, Restricted Client Report No. CAFSS_080, 116 p.

Fitzpatrick, R.W., Raven, M.D., McClure, S., and Forrester, S.T., 2007, Investigation of soil materials adhering to Sandshoes and Grey Tracksuit pants exhibits from the NSW Police Integrity Commission (Balding Case - Stage 2): Centre for Australian Forensic Soil Science, Restricted Client Report No. CAFSS_010, February 2007, 52 p.

Isbell, R.F., National Committee on Soils and Terrain, 2016, The Austra- 
lian soil classification (2 $2^{\text {nd }}$ edition): CSIRO Publishing, Clayton, $141 \mathrm{p}$. Johnston, R.M., Barry, S.J., Bleys E., Bui, E.N., Moran, C.J., Simon, D.A.P., Carlile, P., McKenzie, N.J., Henderson, B.L., Chapman, G., Imhoff, M., Maschmedt, D., Howe, D., Grose, C., and Schoknecht, N., 2003, ASRIS: The database: Australian Journal of Soil Research, v. 41, pp. 10211036.

Martin, B., 2012, The State of Western Australia v. Rayney. [No 3]: WASC, $369 \mathrm{p}$.

McDonald, R., and Isbell., R.F., 2009, Australian soil and land survey: field handbook ( $3^{\text {rd }}$ edition): National Committee on Soil and Terrain, CSIRO Publishing, Melbourne, $265 \mathrm{p}$.

Murray, R.C., 2011, Evidence from the earth: forensic geology and criminal investigation ( $2^{\text {nd }}$ edition): Mountain Press Publishing, Missoula, $200 \mathrm{p}$.

Northcote, K.H., Beckmann, G.G., Bettenay E., Churchward H.M., Van Dijk D.C., Dimmock G.M., Hubble G.D., Isbell R.F.,. McArthur W.M, Murtha, G.G, Nicholls, K.D., Paton, T.R., Thompson, C.H., Webb, A.A., and Wright, M.J., 1960-68, Atlas of Australian Soils. Sheets with explanatory booklets: CSIRO, Publishing, Melbourne.

Pye, K., 2007, Geological and soil evidence: forensic applications: CRC Press, Boca Raton, $335 \mathrm{p}$.

Raven, M.D., Fitzpatrick, R.W., and Self, P.G., 2016, Trace evidence examination using laboratory and synchrotron X-ray diffraction techniques: $35^{\text {th }}$ International Geological Congress, Symposium on Forensic Soil Science and Geology, With $5^{\text {th }}$ International Conference on Criminal and Environmental Soil Forensics ( $5^{\text {th }}$ Soil Forensics International (SFI) Conference), Cape Town, Paper No 1131. http://www.americangeosciences.org/information/igc.

Ritz, K., Dawson, L., and Miller, D. (eds.), 2008, Criminal and environmental soil forensics: Springer Science+Business Media B.V., ISBN 978-1-4020-9204-6.

Ruffell, A., and McKinley, J., 2008, Geoforensics: John Wiley \& Sons, Ltd., Hoboken, 332 p.

Schoeneberger, P.J., Wysocki, D.A., Benham, E.C., and Broderson, W.D., 2002, Field book for describing and sampling soils (version 2.0): Natural Resources Conservation Service, National Soil Survey Center, Lincoln, USA.

Soil Survey Staff, 2014, Keys to soil taxonomy (12 ${ }^{\text {th }}$ edition): United States Department of Agriculture Natural Resources Conservation Service, Washington, D.C.

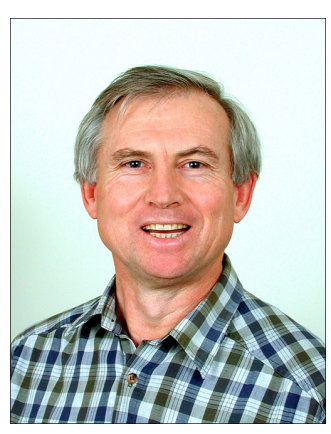

Rob Fitzpatrick is Director of the CAFSS, at CSIRO Land and Water, Principal Consultant of Soil Forensic Solutions, Professorial Research Fellow and Director of the Acid Sulfate Soils Centre, University of Adelaide. $\mathrm{He}$ is a Certified Professional Soil Scientist and has worked on over 150 criminal cases in Australia and overseas. He is a Fellow of the Australian Academy of Technological Sciences and Engineering, Soil Science Society of America, Soil Science Society of Southern Africa and British Society of Soil Science. $\mathrm{He}$ is the recipient of awards from The Australian Society of Soil Science, The Royal Society of South Australia and IUGS-IFG.

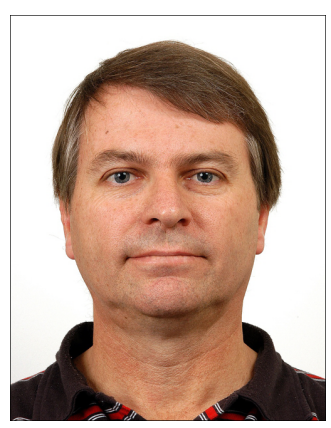

Mark Raven is leader of the Mineralogical and Geochemical Characterisation group, using $\mathrm{X}$-ray Diffraction (XRD) and X-ray Fluorescence (XRF) techniques. He has over 35 years of experience in many aspects of work involving soil mineralogy utilising XRD and XRF analysis. He undertakes research and development of quantitative methods of mineralogical analysis for accurate identification and quantification of minerals in soils and regolith involving the integration of XRD (Rietveld Analysis), XRF and mineral-specific wet chemical techniques. Application of quantitative XRD methods to clay mineralogy is his particular area of expertise.

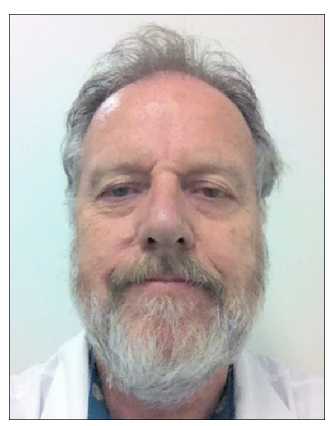

Peter Self trained as a transmission electron microscopist completing a $\mathrm{PhD}$ on electron diffraction at the University of Melbourne. Peter has held positions at the University of Cambridge, Arizona State University, the University of Melbourne, the University of South Australia, and the University of Adelaide. Peter now concentrates his efforts on powder X-ray diffraction at the CSIRO Land and Water laboratories in Adelaide. 